\title{
Academics' Perceptions of the Principles for Responsible Management Education (PRME) for Sustainable Development
}

\author{
Suvera Boodhoo, Sanjana Brijball Parumasur \\ University of the Witwatersrand, Johannesburg, South Africa \\ University of KwaZulu-Natal, Durban, South Africa \\ suvera.boodhoo@wits.ac.za, brijballs@ukzn.ac.za
}

\begin{abstract}
In light of business leaders' failings, including corporate corruption, the financial crisis and various ecological system crises there is a growing expectation that management education institutions should be leading thought and action on issues related to corporate responsibility and sustainability. Therefore, there is a need to ascertain management education institutions' ability to ensure responsible and sustainable management education. This paper seeks to assess academics' perceptions of how the University of KwaZuluNatal has adopted the United Nation (UN) supported initiative, Principles for Responsible Management Education (PRME), to ensure responsible and sustainable management education in South Africa. The sample was drawn using the probability sampling technique called cluster sampling. Permanent academic staff from the Graduate School of Business and Leadership and the School of Management, Information Technology and Governance who responded to the structured, self-administered questionnaire formed the sample. Questions asked related to fostering a sustainable culture, strategically adapting curriculum, creating learning environments, aligning research, fostering sustainable partnerships and encouraging constant dialogue with regards to PRME. In order to assess the implementation of the PRME for sustainable development, a quantitative research design was adopted. This is the first study, to the researcher's knowledge, to examine the University of KwaZulu-Natal's Graduate School of Business and Leadership and the School of Management, Information Technology and Governance's motives, effects and challenges of engaging in PRME. The study has also explored key aspects such as the adaptation of teaching practices by the academic staff, the role of academics and diversification that influences the decision of the Graduate School of Business and Leadership and School of Management, Information Technology and Governance to participate in PRME. The results indicate that academic staff in both schools is engaging in activities that pursue the cause of sustainable development. There is evidence of addressing modern societal and environmental challenges by fostering change in design in curricula, fostering a sustainable culture and creating a learning environment. However, evidently more careful and deliberate attention needs to be given to fostering constant dialogue and aligning PRME and research to enhance economic, environmental and social development. This study provides a model/framework to present current practices and obstacles/setbacks experienced in adopting PRME and will present recommendations to facilitate the adoption of PRME by UKZN.
\end{abstract}

Keywords: Academics' Perceptions, Principles, Responsible Management Education, Sustainable Development

\section{Introduction}

Our modern society is facing very complex issues which demand sustainable and pragmatic solutions. This is complicated by increased ecological, economic and geopolitical uncertainty. In light of business leaders' failings, including corporate corruption, the financial crisis and various ecological system crises, it is evident that education has a major role to play. Addressing these complex issues requires global leaders and citizens who are capable of perspective transformation and are equipped with habit of mind that reflect sustainability concepts. As higher education institutions are in charge of producing future generations of teachers, scientists, engineers, managers and policy makers there is a pressing need for said institutions to practice responsible and sustainable management of education (Erickson, Griswold, Hohn \& Saulters, 2010). The expectation that management education institutions should be leading thought and action on issues related to corporate responsibility and sustainability has been reinforced. The United Nations supported Principles for Responsible Management Education (PRME) initiative is an important catalyst for the transformation of management education and a global initiative to change and reform management education in order to meet the increasing societal demands for responsible business. In order to develop a new generation of business leaders capable of managing the complex challenges faced by business and society in the 21st century, PRME seeks to establish a process of continuous improvement among management education institutions by ensuring that education has purpose, incorporates the values of social responsibility, adopts effective 
learning methods, engages in research contributing to the creation of sustainable value, ensures partnerships with business corporations and dialogue with key role players related to global social responsibility and sustainability. This paper intends to explore how the University of KwaZulu-Natal has adopted the United Nations (UN) supported initiative Principles for Responsible Management Education (PRME) to contribute towards responsible and sustainable management education in South Africa. In particular, it explores how the School of Management, Information Technology and Governance, and the Graduate School of Business are fostering a sustainable culture, fostering change/design in curricula, creating a learning environment, aligning PRME and research and fostering PRME partnerships and constant dialogue to enhance economic, environmental and social development.

\section{Literature Review}

Sustainable development: Sustainable development can be defined as the development which meets the needs of the present without compromising the ability of future generations to meet their own needs (World Commission on Environment and Development, 1987). Furthermore, when human beings strive for enhanced life conditions without diminishing the meaning of life itself, namely, our children's future, one calls this development sustainable. Munasinghe $(2002$, p. 8) states that "while no universally acceptable practical definition of sustainable development exists, the concept has evolved to encompass three major points of view: economic, social and environmental, each viewpoint corresponds to a domain (and a system) that has its own distinct driving forces and objectives". The economy is geared mainly towards improving human welfare, primarily through increases in the consumption of goods and services. The environmental domain focuses on the protection of resilience and integrity and of ecological systems. The social domain emphasizes the enrichment of human relationships, the achievement of individual and group aspirations, and the strengthening of values, beliefs and institutions (Munasinghe, 2002). According to Redclift (2005) and Kunz (2006), the balance between the environmental, economic and social 'pillars' of social development is attained through consideration and has now been incorporated into the mainstream political discourse. Gebreselassie (2010) concurs, stating that sustainable development centres around three core domains, namely, environmental, economic and socio-political sustainability.

Education for sustainable development (ESD), a United Nations (UN) initiative, is a movement advocating for the reorientation of education which emphasizes the development of stewards and citizens who have values, knowledge and skills that support civic engagement, sustainable behaviour, as well as viable employment and an improved quality of life (Egan, 2004; Kevany, 2007; UNESCO, 2005). According to Armstrong (2011, p. 18), "preparing students for lifelong learning is central to this approach, which is an adaptive quality that makes the student more malleable in a time when most societies are experiencing dramatic economic, social and environmental transformation". Consequently, this reorientation is thought to require an entire reconceptualization of how and what students should learn (UNESCO, 2005). In higher education especially, the integration of ESD has been slow (Bosselmann, 2001; Everett, 2008; Rode \& Michelsen, 2008).

In order to address the challenges of the $21^{\text {st }}$ century, the United Nations (UN) has devised the Principles for Responsible Management Education (PRME) which is a United Nations Global Compact sponsored initiative with the mission to inspire and champion responsible management education, research and leadership thought globally. According to Haertle (2012a, p. 4), "the Six Principles of PRME are inspired by internationally accepted values, such as the Ten Principles of the United Nations Global Compact". The United Nations has encouraged higher education institution business schools to adopt the Principles for Responsible Management Education (PRME) into their offered programs. Once higher education institutions have incorporated the six Principles for Responsible Management Education (PRME) they have to adhere too (PRME Steering Committee, 2014). For the purpose of this paper, the major challenges faced in the $21^{\text {st }}$ century have been identified as human rights, poverty, labour, environment and anti-corruption. These challenges are represented in the United Nations Millennium Goals and can also be represented as such: anticorruption and labour as economic development, environment as environmental development, human rights and poverty as social development. The literature on these challenges has been vast but there is very little literature to suggest that these challenges have been incorporated into the education system of universities. Therefore, the management of education cannot be viewed as responsible and sustainable. 
Principles for Responsible Management Education (PRME): Launched at the United Nations Global Compact Leaders' Summit in Geneva, the Principles for Responsible Management Education (PRME) were developed in 2007 by an international task force of sixty Deans, University Presidents and official representatives of leading business schools and academic institutions. According to Haertle (2012a, p. 4), "the Principles for Responsible Management Education initiative is the first organized relationship between business and management schools and the United Nations, with the PRME Secretariat housed in the United Nations Global Compact Office". PRME's fundamental goal is to inspire, encourage and champion responsible management education, research and leadership thought worldwide. Internationally accepted values, such as the United Nations Global Compact's Ten Principles, have been the inspiration for the Six Principles for PRME. The PRME initiative offers an engagement structure for academic institutions by incorporating universal values into research and curricula in order for academic institutions to advance social responsibility. In order to develop a new generation of business leaders capable of managing the complex challenges faced by business and society in the 21st century, PRME seeks to establish a process of continuous improvement among management education institutions (PRME Steering Committee, 2014). The Six Principles are:

- Purpose: "Develop the capabilities of students to be future generators of sustainable value for business and society at large and work for an inclusive and sustainable economy". (Principle 1)

- Value: "Incorporate into academic activities and curricula the values of global social responsibility as portrayed in international initiatives such as the United Nations Global Compact". (Principle 2)

- Method: "Create educational frameworks, materials, processes and environments that enable effective learning experiences for responsible leadership". (Principle 3)

- Research: "Engage in conceptual and empirical research that advances understanding about the roles, dynamics, and impact of corporations in the creation of sustainable social, environmental and economic value". (Principle 4)

- Partnership: "Interact with managers of business corporations to extend the knowledge on the challenges they face in meeting social and environmental responsibilities and to explore jointly effective approaches to meeting these challenges". (Principle 5)

- Dialogue: "Facilitate and support dialog and debate among educators, students and business, government, consumers, media, civil society organizations and other interested groups and stakeholders on critical issues related to global social responsibility and sustainability". (Principle 6) (PRME Steering Committee, 2014).

The PRME initiative as a framework, serves as a gradual, systematic change in management-related institutions and business schools, based on three distinctive characteristics of the initiative: learning network, reporting progress to stakeholders and continuing improvements. As a participant institution, reporting to stakeholders through Sharing Information on Progress (SIP) is a crucial part of active commitment to PRME. "SIP reporting provides an opportunity for exchanging effective practices and information on progress achieved in the implementation of PRME, resulting in the creation of a learning community with other participating business and management institutions" (PRME Steering Committee, 2014).

Purpose of PRME: The United Nations supported initiative 'Principles for Responsible Management Education' (PRME) addresses the responsibilities of management education institutions in preparing today's and tomorrow's business professions for the challenge of bringing about more responsible and sustainable business. It expects fundamental changes to the conduct of business, on the assumption that companies have wider responsibilities for society and the environment than simply profitability and meeting shareholders' interests. The expectation that management education institutions should be leading thought and action on issues related to social responsibility and sustainability has been reinforced in the light of their association with business leaders' failings, regarding corporate corruption, for example, Enron, Siemens, UBS, and economic failings such as, the financial sector meltdown and ecological setbacks, for example, regarding global warming system failings. Given their critical role in management education (for example, as one of the financial sector's main recruitment source) they have frequently been singled out by their stakeholders as having a particular responsibility in the broad agenda for social, economic and ecological sustainability (Khurana, 2010; Khurana \& Nohria, 2008). In response to these criticisms, some efforts have been made to advance business ethics and corporate social responsibility education (Matten \& Moon, 2005; Moon \& Orlitzky, 2011; Orlitzky \& Moon, 2010). Nonetheless, the challenge remains rethinking management and 
leadership education (Global Responsibility Leadership Initiative, 2012). In this context, PRME has been referred to as the key catalyst for the transformation of management education and for necessary changes required to meet the increasing societal demands for a responsible economy (Haertle, 2012b; Rasche \& Kell, 2010; Waddock, Rasche, Wehane \& Unruh, 2011).

Engaging higher education institutions in the challenge of sustainability: In order to meet climate challenges faced by citizens of the world, the current business landscape has created the need to develop and equip management graduates with capabilities that foster sustainability and responsible leadership (Young \& Nagpal, 2013). In the development of management graduates, citizens of the world have to alter their behaviour and the systems that support human civilization, such as the social, economic and political governance. The changes that are required are needed within corporations in their relations with media, customers, governments, suppliers, competitors, civil society, including external systems. Management education needs to adapt existing knowledge to include issues of climate and sustainability within core disciplines as part of the new business imperative, thus assisting with dealing with the needed change effectively. Young and Nagpal (2013, p. 498) espouse that "climate challenge is multi-disciplinary and the responses must be based on multi-stakeholder dialogue on climate change among educators, students, and other stakeholders such as, but not limited to, governments, business practitioners, local and global communities and NGOs". As advanced by the United Nations Global Compact, low carbon innovation and climate action is part of the bigger sustainability agenda, whose values have inspired the Principles for Responsible Management Education (PRME). Along with the three related global risks such as the food crises, water sustainability and energy uncertainties, the pivotal problem of climate change requires simultaneous attention to the preservation of the basis of human growth.

Evidently, a new education system must be envisioned, one that is capable of addressing modern societal and environmental challenges in all their complexities. In order to stay in tune with the global development on these issues the United Nations Principles for Responsible Management Education (UNPRME) can be used as a guide for delivering sustainability-focused management education and providing an opportunity to structure the change process and to offer support through partnerships (Sterling, 2001). Young and Nagpal (2013, p. 497) observed that "there has been increased debate over how to adapt management education to best meet the demands of the 21st century business environment, since the inception of the United Nations Global Compact sponsored initiative Principles for Responsible Management Education (PRME) in 2007". While the majority of globally focused management education institutions have reached consensus on incorporating sustainability into the management education curricula, the overarching question is no longer why management education should change but rather how?

\section{Methodology}

Research approach: The research methodology has been designed to undertake a quantitative, crosssectional study to assess academics' perceptions of the principles for responsible management education (PRME) for sustainable development.

Research participants: The population comprised of all academic staff in the Graduate School of Business and the School of Management, Information Technology and Governance which consists of 92 staff members from which a sample of 74 employees was drawn using cluster sampling. Although the desired sample size was not achieved, the adequacy of the sample was determined using the Kaiser-Meyer-Olkin Measure of Sampling Adequacy (0.792) and the Bartlett's Test of Spherecity (232.818, p $=0.000$ ) which respectively indicated suitability and significance. The results indicate that the normality and homoscedasticity preconditions are satisfied. The composition of the sample may be described in terms of age, gender, race, discipline and position. The majority of academics that responded are $>40$ years ( $40 \%)$, followed by those who are 36-40 years of age (30\%). More female (53.3\%) than male academics (46.7\%) participated, with the majority of participants being Black (46.7\%) followed by Indians (43.4\%). Furthermore, the majority of the participants are at the lecturer level (53.3\%), and from the Discipline of Human Resource Management and Industrial Relations (26.7\%) with an equal number being from Marketing and Supply Chain $(23.3 \%)$ and the Graduate School of Business (23.3\%). 
Measuring instrument: Data was collected using a self-developed questionnaire consisting of five sections, namely, Sections A, B, C, D and E. Section A enlisted the respondents' demographic profile which included age, gender, race, position currently held and discipline which he/she belongs to which were measured using a nominal scale. Section B was constructed to assess the perceptions of academics regarding the background of economic development (anti-corruption and labour), environmental development and social development (human rights and poverty). Section $\mathrm{C}$ was designed to assess academics' perceptions of the Principles for Responsible Management Education (PRME), with a focus on:

- Fostering a sustainable culture centered on economic, environmental and social development.

- Fostering change/design in curricula centered on economic, environmental and social development.

- Creating a learning environment conducive to economic, environmental and social development.

- Aligning PRME and research on economic, environmental and social development.

- Fostering PRME partnerships to enhance economic, environmental and social development.

- Fostering constant dialogue to enhance economic, environmental and social development.

Section D tapped into academics' perceptions of sustainable development and Section E assessed staff perceptions of the link of the dimensions of economic, environmental and social development with the six Principles for RME. Sections B, C, D and E utilized a 5 point Likert scale.

In-house pretesting was adopted to assess the suitability of the instrument. Pilot testing was also undertaken by administering the questionnaire to 3 academics. The feedback from the pilot testing confirmed that the questionnaire was appropriate in terms of relevance, wording and construction. The validity of the questionnaire was assessed using Factor Analysis. A principal component analysis was used to extract initial factors and an iterated principal factor analysis was performed using SPSS with an Orthogonal Varimax Rotation. Only items with loadings $>0.4$ were considered to be significant. Furthermore, when items were significantly loaded on more than one factor only that with the highest value was selected. In terms of the anticipated dimensions of the study, 7 factors with latent roots greater than unity were extracted from the factor loading matrix as originally designed, thereby confirming the validity of the questionnaire (Table 1).

\section{Table 1: PRME Measuring Instrument (Academics): Factor Analysis}

\begin{tabular}{lll}
\hline Factor & Eigenvalue & Factor Name \\
\hline 1 & 11.779 & $\begin{array}{l}\text { Sustainable development } \\
\text { Fostering PRME partnerships to enhance economic, environmental and social } \\
\text { development }\end{array}$ \\
3 & 7.539 & $\begin{array}{l}\text { Fostering change/design in curricula centered on economic, environmental and } \\
\text { social development }\end{array}$ \\
4 & 5.012 & $\begin{array}{l}\text { Fostering a sustainable culture centered on economic, environmental and social } \\
\text { development. }\end{array}$ \\
5 & 3.822 & $\begin{array}{l}\text { Aligning PRME and research on economic, environmental and social development } \\
\text { Creating a learning environment conducive to economic, environmental and social } \\
\text { development } \\
6\end{array} 3.237$ \\
7 & 3.042 & $\begin{array}{l}\text { Fostering constant dialogue to enhance economic, environmental and social } \\
\text { development }\end{array}$ \\
\hline
\end{tabular}

The overall reliability of the questionnaire was determined using Cronbach's Coefficient Alpha (Alpha = 0.982). This coefficient alpha indicates a very high level of internal consistency of the items and, hence, a high degree of reliability.

Research procedure: The questionnaires were administered personally by the researcher and a research assistant over a six month period and during a PRME Workshop held in the School of Management, Information Technology and Governance.

Statistical analyses: Descriptive and inferential (correlation, ANOVA, Post-Hoc Scheffe's test, t-test, multiple regression) statistics were used to analyze the quantitative data. 
Table 2: Reliability of the measuring instrument (Academics): Cronbach's Coefficient Alpha

\begin{tabular}{lc}
\hline Dimension & Reliability \\
\hline Creating a learning environment conducive to economic, environmental and social & \\
development & 0.837 \\
Aligning PRME and research on economic, environmental and social development & 0.904 \\
Fostering PRME partnerships to enhance economic, environmental and social development & 0.918 \\
Fostering constant dialogue to enhance economic, environmental and social development & 0.919 \\
Fostering change/design in curricula centered on economic, environmental and social & 0.920 \\
development & \\
Sustainable development & 0.942 \\
Fostering a sustainable culture centered on economic, environmental and social development & 0.962 \\
Overall Questionnaire & 0.982 \\
\hline
\end{tabular}

Table 2 indicates that the reliabilities of the respective principles for responsible management education and sustainable development range from 0.837 to 0.962 , thereby reflecting a very high level reliability across all dimensions.

\section{Results}

The perceptions of academic staff of the Principles for Responsible Management Education (PRME) are analysed using descriptive and inferential statistics.

Descriptive Statistics: Academics' perceptions of PRME and Sustainable Development: Academic staff members were asked questions with regards to fostering a sustainable culture, fostering change and design, creating a learning culture, aligning PRME and research, fostering PRME partnerships, fostering constant dialogue and sustainable development centred on economic, environmental and social development. This was accomplished by making use of a five point Likert scale.

Table 3: Descriptive statistics: Academics' perceptions of PRME and Sustainable Development

\begin{tabular}{|c|c|c|c|c|c|c|c|}
\hline \multirow[t]{2}{*}{ Dimension } & \multirow[t]{2}{*}{ Mean } & \multicolumn{2}{|c|}{ Critical Range } & \multirow[t]{2}{*}{ Variance } & \multirow[t]{2}{*}{ Std. Dev. } & \multirow[t]{2}{*}{ Min. } & \multirow[t]{2}{*}{ Max } \\
\hline & & $\begin{array}{l}\text { Lower } \\
\text { Bound }\end{array}$ & $\begin{array}{l}\text { Upper } \\
\text { Bound }\end{array}$ & & & & \\
\hline \multicolumn{8}{|l|}{ Fostering a sustainable culture } \\
\hline & 3.624 & 3.265 & 3.983 & 0.923 & 0.961 & 1 & 5 \\
\hline Fostering change and design & 3.850 & 3.527 & 4.1720 & 0.748 & 0.865 & 1 & 5 \\
\hline Creating a learning culture & 3.572 & 3.277 & 3.868 & 0.626 & 0.791 & 1 & 5 \\
\hline & 3.072 & 2.685 & 3.459 & 1.074 & 1.036 & 1 & 5 \\
\hline \multirow[t]{2}{*}{ Fostering PRME partnerships } & & & & & & & \\
\hline & 3.300 & 2.936 & 3.664 & 0.951 & 0.975 & 1 & 5 \\
\hline Fostering constant dialogue & 3.106 & 2.724 & 3.487 & 1.043 & 1.021 & 1 & 5 \\
\hline Sustainable development & 3.133 & 2.743 & 3.523 & 1.091 & 1.045 & 1 & 5 \\
\hline
\end{tabular}

The perception of academics of the Principles for Responsible Management Education (fostering a sustainable culture, fostering change and design, creating a learning culture, aligning PRME and research, fostering PRME partnerships, fostering constant dialogue centred on economic, environmental and social development) and sustainable development in descending level based on mean score values are:

- $\quad$ Fostering change and design (Mean $=3.850)$

- Fostering a sustainable culture $($ Mean $=3.624)$

- $\quad$ Creating a learning culture (Mean $=3.572)$

- Fostering PRME partnerships (Mean $=3.300)$

- Sustainable development (Mean = 3.133)

- Fostering constant dialogue (Mean $=3.106)$

- Aligning PRME and research (Mean = 3.072) (Table 3). 
From the aforementioned it is evident that academics believe that the schools concerned are fostering change and design in curricula centered on economic, environmental and social development. However, they are least convinced that the schools are aligning PRME and research centered on economic, environmental and social development. In order to engage in in-depth analyses of academics' perceptions of the principles and dimensions for PRME, frequency analyses were conducted and are consolidated in terms of strengths and areas for improvement in Table 4.

Table 4: Frequency Analyses: Principles and dimensions of PRME - Strengths and Weaknesses

\begin{tabular}{|c|c|c|}
\hline Principle & Strengths & Area for Improvement \\
\hline & $\begin{array}{l}\text { Within the degree academics lecture in, their } \\
\text { modules: }\end{array}$ & $\begin{array}{l}\text { Within the degree academics lecture in, } \\
\text { their modules: }\end{array}$ \\
\hline $\begin{array}{l}\text { Fostering } \\
\text { change and } \\
\text { design }\end{array}$ & $\begin{array}{l}\text { - ... emphasize the importance of ethical } \\
\text { conduct in business. } \\
\text { in society and work environment. }\end{array}$ & $\begin{array}{l}\text {.... there is no engagement on issues } \\
\text { recognising the right of collective } \\
\text { bargaining and freedom of association in } \\
\text { the work environment. }\end{array}$ \\
\hline $\begin{array}{l}\text { Fostering a } \\
\text { sustainable } \\
\text { culture }\end{array}$ & $\begin{array}{l}\text {.... are highly recognised in the market, } \\
\text { making it easier for students to secure a job and } \\
\text { improve their human welfare. }\end{array}$ & $\begin{array}{l}\text {-... do not cater for them to continuously } \\
\text { encourage students to have greater } \\
\text { environmental responsibility and take } \\
\text { cognisance of environmental challenges. }\end{array}$ \\
\hline $\begin{array}{l}\text { Creating a } \\
\text { learning } \\
\text { culture }\end{array}$ & $\begin{array}{l}\text {.... use real-life case studies that provide } \\
\text { students with first-hand experience of the job } \\
\text { market in terms of factors that hinder, and } \\
\text { strategies for enhancing, economic development. } \\
\text { - ... are designed with an e-learning } \\
\text { component that facilitates learning in addition to } \\
\text { traditional lecture methods. }\end{array}$ & $\begin{array}{l}\text {-... are not sufficiently designed in a } \\
\text { manner that requires prospective } \\
\text { students to access information on anti- } \\
\text { corruption outside of the traditional } \\
\text { learning environment. } \\
\text { The School does not sufficiently embrace } \\
\text { going green and this is evident in its daily } \\
\text { operations including increased online } \\
\text { interactions }\end{array}$ \\
\hline $\begin{array}{l}\text { Fostering } \\
\text { PRME } \\
\text { partnerships }\end{array}$ & $\begin{array}{l}\text { The School supports partnerships with } \\
\text { environmentally responsible organisations. } \\
\text { - The School supports the invitation of } \\
\text { guest lecturers from corporations to enlighten } \\
\text { students on the challenges that they face as a } \\
\text { result of corruption, environmental degradation } \\
\text { and/or violation of human rights and poverty. }\end{array}$ & $\begin{array}{l}\text {.... do not incorporate the use of case } \\
\text { studies to emphasise the importance of } \\
\text { partnering with corporations that adhere } \\
\text { to human rights. }\end{array}$ \\
\hline $\begin{array}{l}\text { Fostering } \\
\text { constant } \\
\text { dialogue }\end{array}$ & $\begin{array}{l}\text { Guest lecturers are invited and/or } \\
\text { students are encouraged to engage in discussions } \\
\text { around labour and skills utilisation for human } \\
\text { and economic development. } \\
\text { discussions/presentations regarding social } \\
\text { diversity and interaction amongst all groups in a } \\
\text { socially sustainable system that shapes the } \\
\text { process of development. }\end{array}$ & $\begin{array}{l}\text {... do not enable constant dialogue and } \\
\text { debates on climate change. } \\
\text {.... do not require students to engage in } \\
\text { discussions/presentations regarding } \\
\text { environmental degradation and its } \\
\text { prevention. }\end{array}$ \\
\hline $\begin{array}{l}\text { Aligning } \\
\text { PRME and } \\
\text { research }\end{array}$ & $\begin{array}{l}\text { Academics' reading and exposure to } \\
\text { literature within the modules they lecture have } \\
\text { enlightened them on the minimum international } \\
\text { standards for individual protection of rights and } \\
\text { freedom. }\end{array}$ & $\begin{array}{l}\text { - Within their appointment, academics are } \\
\text { not forced to engage in empirical } \\
\text { research centered on understanding and } \\
\text { fighting corruption and/or its impact on } \\
\text { human and economic development. }\end{array}$ \\
\hline & $\begin{array}{l}\text { The assignments that academics prepare } \\
\text { require students to understand the relationship } \\
\text { between poverty and socioeconomic, } \\
\text { geographical and political conditions in South } \\
\text { Africa and/or brainstorm on strategies for } \\
\text { poverty reduction. }\end{array}$ & $\begin{array}{l}\text {... does not require them to engage in } \\
\text { research that advances knowledge on } \\
\text { climate change. }\end{array}$ \\
\hline
\end{tabular}


Inferential Statistics: Staff perception of PRME and Sustainable Development: Inferential statistics were computed to test the hypotheses of the study and draw conclusions with regards to academic's perceptions of PRME and sustainable development.

Hypothesis 1: There exists significant intercorrelations amongst academic staff perceptions of the Principles for Responsible Management Education (fostering a sustainable culture, fostering change and design, creating a learning environment, aligning PRME and research, fostering PRME partnerships, fostering constant dialogue) respectively (Table 5).

Table 5: Intercorrelation amongst the Principles for Responsible Management Education (Academics)

\begin{tabular}{|c|c|c|c|c|c|c|c|}
\hline Dimension & $\mathbf{r} / \mathbf{p}$ & $\begin{array}{l}\text { Fostering a } \\
\text { sustainable } \\
\text { culture }\end{array}$ & $\begin{array}{l}\text { Fostering } \\
\text { change and } \\
\text { design }\end{array}$ & $\begin{array}{l}\text { Creating a } \\
\text { learning } \\
\text { environment }\end{array}$ & $\begin{array}{l}\text { Aligning } \\
\text { PRME and } \\
\text { research }\end{array}$ & $\begin{array}{l}\text { Fostering } \\
\text { PRME } \\
\text { partnerships }\end{array}$ & $\begin{array}{l}\text { Fostering } \\
\text { constant } \\
\text { dialogue }\end{array}$ \\
\hline Fostering a & $r$ & 1000 & & & & & \\
\hline Fostering change & $\mathrm{r}$ & $\begin{array}{l}0.707 \\
0.000 *\end{array}$ & 1.000 & & & & \\
\hline $\begin{array}{l}\text { Creating a learning } \\
\text { environment }\end{array}$ & $\begin{array}{l}\mathrm{r} \\
\mathrm{p}\end{array}$ & $\begin{array}{l}0.758 \\
0.000^{*}\end{array}$ & $\begin{array}{l}0.595 \\
0.001^{*}\end{array}$ & 1.000 & & & \\
\hline $\begin{array}{l}\text { Aligning PRME and } \\
\text { research }\end{array}$ & r & $\begin{array}{l}0.662 \\
0.001 *\end{array}$ & $\begin{array}{l}0.569 \\
0.001 *\end{array}$ & $\begin{array}{l}0.608 \\
0.000^{*}\end{array}$ & 1.000 & & \\
\hline $\begin{array}{l}\text { Fostering PRME } \\
\text { partnerships }\end{array}$ & $\begin{array}{l}\mathrm{r} \\
\mathrm{p}\end{array}$ & $\begin{array}{l}0.748 \\
0.000^{*}\end{array}$ & $\begin{array}{l}0.569 \\
0.001 *\end{array}$ & $\begin{array}{l}0.666 \\
0.000^{*}\end{array}$ & $\begin{array}{l}0.682 \\
0.000^{*}\end{array}$ & 1.000 & \\
\hline $\begin{array}{l}\text { Fostering constant } \\
\text { dialogue }\end{array}$ & $\begin{array}{l}\mathrm{r} \\
\mathrm{p}\end{array}$ & $\begin{array}{l}0.723 \\
0.000^{*}\end{array}$ & $\begin{array}{l}0.613 \\
0.000^{*}\end{array}$ & $\begin{array}{l}0.724 \\
0.000^{*}\end{array}$ & $\begin{array}{l}0.803 \\
0.000^{*}\end{array}$ & $\begin{array}{l}0.633 \\
0.000^{*}\end{array}$ & 1.000 \\
\hline
\end{tabular}

$* \mathrm{p}<0.01$

Table 5 indicates that there exists significant intercorrelations amongst academics' perceptions of the principles for responsible management education (fostering a sustainable culture, fostering change and design, creating a learning environment, aligning PRME and research, fostering PRME partnerships, fostering constant dialogue) respectively, at the $1 \%$ level of significant. Hence, Hypothesis 1 may be accepted. Table 5 also indicates that the dimensions relate to each other in varying degrees. Significant and strong relationships exist between fostering a sustainable culture and fostering change and design $(r=0.707)$, creating a learning environment $(\mathrm{r}=0.758)$, fostering PRME partnerships $(\mathrm{r}=0.748)$ and fostering constant dialogue $(r=0.723)$ respectively. Furthermore, significant and strong relationships were noted between fostering constant dialogue and creating a learning environment $(r=0.724)$ and aligning PRME and research $($ Mean $=0.803)$ respectively.

Furthermore, Table 5 indicates that significant and moderate relationships exist between fostering a sustainable culture and aligning PRME and research $(\mathrm{r}=0.662)$. Furthermore, Table 5 reflects that significant and moderate relationships exist between fostering change and design and all the other principles for management education (creating a learning environment, aligning PRME and research, fostering PRME partnerships, fostering constant dialogue) respectively. In addition, Table 5 indicates that significant and moderate relationship exist between creating a learning environment and aligning PRME and research $(\mathrm{r}=$ $0.608)$ and fostering PRME partnerships $(r=0.666)$ respectively. Also, Table 5 indicates that a significant and moderate relationship exists between aligning PRME and research and fostering PRME partnerships $(\mathrm{r}=$ 0.682) and between fostering PRME partnerships and fostering constant dialogue $(r=0.633)$.

Hypothesis 2: The Principles for Responsible Management Education (fostering a sustainable culture, fostering change and design, creating a learning environment, aligning PRME and research, fostering PRME partnerships, fostering constant dialogue) as perceived by academics significantly relate to sustainable development) (Table 6).

From Table 6 it is evident that the Principles for Responsible Management Education (fostering a sustainable culture, fostering change and design, creating a learning environment, aligning PRME and research, fostering PRME partnerships, fostering constant dialogue) as perceived by academics significantly relate to sustainable 
development at the $1 \%$ level of significance. Hence, Hypothesis 2 may be accepted. Table 6 also reflects that, based on academics' perceptions, the strongest relationship lies between the principle of fostering constant dialogue and sustainable development $(r=0.818)$ followed by aligning PRME and research and sustainable development $(r=0.733)$ and closely followed by creating a learning environment and sustainable development $(r=0.709)$. Based on academics' perceptions, the remaining principles for PRME moderately relate to sustainable development.

Table 6: Pearson Correlation: Principles for Responsible Management Education (PRME) and Sustainable Development (Academic)

\begin{tabular}{lll}
\hline Dimension & r/p & Sustainable development \\
\hline Fostering a sustainable culture & $\mathrm{r}$ & 0.642 \\
Fostering change and design & $\mathrm{p}$ & $0.000^{*}$ \\
& $\mathrm{r}$ & 0.649 \\
Creating a learning environment & $\mathrm{p}$ & $0.000^{*}$ \\
& $\mathrm{r}$ & 0.709 \\
Aligning PRME and research & $\mathrm{p}$ & $0.000^{*}$ \\
& $\mathrm{r}$ & 0.733 \\
Fostering PRME partnerships & $\mathrm{p}$ & $0.000^{*}$ \\
Fostering constant dialogue & $\mathrm{r}$ & 0.546 \\
& $\mathrm{p}$ & $0.000^{*}$ \\
\hline
\end{tabular}

$* \mathrm{p}<0.01$

Hypothesis 3: There is a significant difference in the perception of academics varying in biographical profiles (age, race, discipline, position, gender) regarding the principles for responsible management education (fostering a sustainable culture, fostering change and design, creating a learning environment, aligning PRME and research, fostering PRME partnerships, fostering constant dialogue) and sustainable development respectively (Table 7 to Table 9).

Table 7: ANOVA-Biographical variables (age, race, discipline, position) and PRME and sustainable development (Academics)

\begin{tabular}{lllllllll}
\hline Dimension & Age & & \multicolumn{2}{c}{ Race } & \multicolumn{2}{c}{ Discipline } & \multicolumn{2}{c}{ Position } \\
& $\mathbf{F}$ & $\mathbf{p}$ & $\mathbf{F}$ & $\mathbf{p}$ & $\mathbf{F}$ & $\mathbf{P}$ & $\mathbf{F}$ & $\mathbf{p}$ \\
\hline Fostering a sustainable culture & 4.980 & $0.007^{*}$ & 1.078 & 0.389 & 0.505 & 0.798 & 0.386 & 0.764 \\
Fostering change and design & 1.913 & 0.152 & 0.160 & 0.956 & 0.507 & 0.796 & 0.836 & 0.486 \\
Creating a learning environment & 6.164 & $0.003^{*}$ & 0.893 & 0.483 & 1.490 & 0.226 & 0.471 & 0.705 \\
Aligning PRME and research & 5.165 & $0.006^{*}$ & 0.842 & 0.512 & 0.862 & 0.537 & 0.752 & 0.531 \\
Fostering PRME partnerships & 2.894 & 0.054 & 1.808 & 0.159 & 0.735 & 0.626 & 0.933 & 0.439 \\
Fostering constant dialogue & 3.517 & $0.029^{* *}$ & 1.242 & 0.319 & 1.673 & 0.173 & 0.804 & 0.503 \\
Sustainable development & 12.566 & $0.000^{*}$ & 1.332 & 0.286 & 1.351 & 0.276 & 1.649 & 0.202 \\
\hline
\end{tabular}

$* \mathrm{p}<0.01$

$* * \mathrm{p}<0.05$

Table 7 indicates that there is a significant difference in the perceptions of academics varying in age regarding fostering a sustainable culture, creating a learning environment, aligning PRME and research, and sustainable development at the $1 \%$ level of significance. Furthermore, there is a significant difference in the perceptions of academics varying in age regarding the principle of fostering constant dialogue at the $5 \%$ level of significance. However, there is no significant difference in the perceptions of academics varying in age regarding fostering change and design and fostering PRME partnerships respectively. Therefore, Hypothesis 3 may be partially accepted in terms of age. Table 7 also reflects that there are no significant differences in the perception of academics varying in race, discipline and position regarding the principles for responsible management education (fostering a sustainable culture, fostering change and design, creating a learning environment, aligning PRME and research, fostering PRME partnerships, fostering constant dialogue) and sustainable development respectively. Therefore, Hypothesis 3 may not be accepted in terms of race, 
discipline and position. In order to assess exactly where the significant differences in academics' perceptions, based on age, lie the Post-Hoc Sceffe's Test was computed (Table 8).

Table 8: Post-Hoc Scheffe's Test: Age and PRME dimensions (Academics)

\begin{tabular}{llrl}
\hline Dimension & Categories of Age & N & Mean \\
\hline Fostering a sustainable culture & $26-30$ years & 3 & 3.370 \\
& $31-35$ years & 6 & 3.037 \\
& $36-40$ years & 9 & 2.519 \\
Creating a learning environment & $>40$ years & 12 & 3.852 \\
& $26-30$ years & 3 & 3.000 \\
& $31-35$ years & 6 & 3.778 \\
Aligning PRME and research & $36-40$ years & 9 & 2.963 \\
& $>40$ years & 4.069 \\
Fostering constant dialogue & $26-30$ years & 3.500 \\
& $31-35$ years & 3 & 3.194 \\
Sustainable development & $36-40$ years & 6 & 2.148 \\
& $>40$ years & 9 & 3.597 \\
& $26-30$ years & 12 & 2.889 \\
& $31-35$ years & 3 & 3.306 \\
\hline
\end{tabular}

Table 8 indicates that academics between the ages of 36-40 years are least convinced that the schools concerned are fostering a sustainable culture, creating a learning environment, aligning PRME and research, fostering constant dialogue and sustainable development as compared to all other academics. Table 8 also reflects that academics who are $>40$ years are most convinced that these principles for responsible management education and sustainable development are being achieved by the schools concerned.

Table 9: t-TEST-Gender and PRME dimensions (Staff)

\begin{tabular}{|c|c|c|c|c|c|c|c|}
\hline \multirow[t]{3}{*}{ Dimension } & \multicolumn{4}{|c|}{ Gender } & \multirow[t]{3}{*}{$\mathbf{T}$} & \multirow[t]{3}{*}{ Df } & \multirow[t]{3}{*}{$\mathbf{p}$} \\
\hline & \multicolumn{2}{|c|}{ Male } & \multicolumn{2}{|c|}{ Female } & & & \\
\hline & & Mean & $\mathbf{N}$ & Mean & & & \\
\hline Fostering a sustainable culture & 14 & 3.72 & 16 & 3.54 & 0.530 & 28 & 0.600 \\
\hline Fostering change and design & 14 & 4.02 & 16 & 3.70 & 1.031 & 28 & 0.311 \\
\hline Creating a learning environment & 14 & 3.60 & 16 & 3.55 & 0.147 & 28 & 0.885 \\
\hline Aligning PRME and research & 14 & 3.26 & 16 & 2.91 & 0.936 & 28 & 0.357 \\
\hline Fostering PRME partnerships & 14 & 3.35 & 16 & 3.26 & 0.234 & 28 & 0.817 \\
\hline Fostering constant dialogue & 14 & 3.20 & 16 & 3.02 & 0.479 & 28 & 0.635 \\
\hline Sustainable development & 14 & 3.31 & 16 & 2.98 & 0.860 & 28 & 0.397 \\
\hline
\end{tabular}

Table 9 indicates that there are no significant differences in the perceptions of male and female academics regarding the principles for responsible management education (fostering a sustainable culture, fostering change and design, creating a learning environment, aligning PRME and research, fostering PRME partnerships, fostering constant dialogue) and sustainable development respectively. Hypothesis 3 may not be accepted in terms of gender.

Hypothesis 4: The Principles of Responsible Management Education (fostering a sustainable culture, fostering change and design, creating a learning culture, aligning PRME and research, fostering PRME partnerships, fostering constant dialogue centred on economic, environmental and social development), as perceived by academics, significantly account for the variance in sustainable development (Table 10). 
Table 10: Multiple Regression: Sustainable development and PRME (Academics)

\begin{tabular}{|c|c|c|c|c|c|}
\hline $\begin{array}{l}\text { Model Summary } \\
\text { Model }\end{array}$ & $\mathbf{R}$ & R Square & Adjusted R Square & $\begin{array}{l}\text { Std. I } \\
\text { Estimat }\end{array}$ & rror of the \\
\hline 1 & $0.861^{\mathrm{a}}$ & 0.741 & 0.673 & 0.59704 & \\
\hline ANOVA $^{\mathrm{a}}$ & & & & & \\
\hline Model & Sum of Squares & Df & Mean Square & $\mathbf{F}$ & Significance \\
\hline $1 \quad$ Regression & 23.441 & 6 & 3.907 & 19.960 & 0.000 \\
\hline Residual & 8.198 & 23 & 0.356 & & \\
\hline Total & 31.640 & 29 & & & \\
\hline Coefficients & & & & & \\
\hline Model & & Unstan & rdized coefficients & Standardi & ed coefficients \\
\hline & & B & Std. Error & Beta & \\
\hline (Constant) & & -0.467 & 0.583 & & \\
\hline Fostering a sustainal & e culture & -0.058 & 0.238 & -0.054 & \\
\hline Fostering change an & design & 0.256 & 0.188 & 0.212 & \\
\hline Creating a learning c & lture & 0.336 & 0.237 & 0.255 & \\
\hline Aligning PRME and $r$ & search & 0.223 & 0.202 & 0.222 & \\
\hline Fostering PRME par & erships & -0.155 & 0.197 & -0.144 & \\
\hline Fostering constant $d$ & logue & 0.466 & 0.225 & 0.456 & \\
\hline
\end{tabular}

Table 10 indicates that the Principles of Responsible Management Education (fostering a sustainable culture, fostering change and design, creating a learning culture, aligning PRME and research, fostering PRME partnerships, fostering constant dialogue centred on economic, environmental and social development) significantly account for $67.3 \%$ of the variance in sustainable development. Hence, Hypothesis 4 may be accepted at the $1 \%$ level of significance. The remaining $32.7 \%$ may be due to other factors that lie outside the jurisdiction of the study. Table 10 also reflects that the Principles of Responsible Management Education impact on sustainable development in varying degrees, which in descending level of impact based on Beta loadings are:

- Fostering constant dialogue to enhance economic, environmental and social development

- Creating a learning culture conducive to economic, environmental and social development

- Aligning PRME and research centered on economic, environmental and social development

- Fostering change and design in curricula centered on economic, environmental and social development

- Fostering PRME partnerships to enhance economic, environmental and social development

- Fostering a sustainable culture centered on economic, environmental and social development

Discussion of results: From the results of the study it is evident that the academic staff in both schools is, either knowingly or unknowingly, engaging in activities that pursue the cause of sustainable development. There is evidence of addressing modern societal and environmental challenges especially through:

- Fostering change/design in curricula centered on economic, environmental and social development.

- Fostering a sustainable culture centered on economic, environmental and social development.

- Creating a learning environment conducive to economic, environmental and social development, and

- Fostering PRME partnerships to enhance economic, environmental and social development.

- With regards to the aforementioned, academics believe that their modules emphasize the importance of ethical conduct in business, are highly recognised in the market and enable their students to secure jobs, have an e-learning component in their modules and ensure partnerships with corporations that are environmentally responsible, especially through guest lectures. Whilst academics use real-life case studies that provide students with first-hand experiences of the factors that hinder and strategies for enhancing economic development, they acknowledge the paucity of partnerships with corporations that adhere to human rights. Evidently, whilst some degree of satisfaction in achieving the aforementioned principles have been expressed by academics, they also identify specific drawbacks and areas of improvement: 
- The modules do not allow engagement on issues of recognising the right of collective bargaining and freedom of association in the work environment.

- Students are not encouraged to access information on anti-corruption outside of the traditional learning environment.

- The schools do not sufficiently embrace going green in its daily operations.

In addition to the aforementioned, the results indicate that schools aiming to further the PRME agenda and contribute to global development need to pay more careful and deliberate attention to the remaining 2 principles for responsible management education, namely:

- Fostering constant dialogue to enhance economic, environmental and social development, and

- Aligning PRME and research on economic, environmental and social development.

With regards to these 2 principles for responsible management education, academics are predominantly of the view that their modules do not accommodate for constant dialogue on climate change or require students to engage in discussions/presentations regarding environmental degradation and its prevention. Furthermore, nearly half of the academics emphasize that they do not, and are not encouraged to, engage in research centered on understanding and fighting corruption and/or brainstorm on strategies for poverty reduction or that advances knowledge on climate change. Contrary to the aforementioned findings, several researchers (Cotton, Bailey, Warren \& Bissell, 2009; De le Harpe \& Thomas, 2009; Sterling \& Scott, 2008; Wals, 2009) found that research initiatives and campus greening are the most notably marked progress at higher education institutions. The aforementioned drawbacks in the pursuit for the PRME act as obstacles for attaining sustainable development. This is visibly evident in the fact that nearly half of the academics are not convinced that their lectures incorporate the values of Global Social Responsibility relating to economic, environmental and social development, nor emphasize that climate change is a business reality and represents an unprecedented challenge for human society and that curricula have changed to introduce climate change issues. Likewise, Cotton et al. (2009), de le Harpe \& Thomas (2009), Sterling \& Scott (2008) and Wals (2009) noted that pedagogical practice has been much slower to develop.

The results of the study also reflect that the 6 principles for responsible management education significantly intercorrelate with each other thereby emphasizing that any improvement in adopting and enhancing any one of these principles will have a snowballing and rippling effect to improve all other principles for responsible management education. One can only imagine the tremendous improvement that can be achievement in management education should ongoing efforts be directed to enhancing the incorporation and adherence of all 6 principles. Likewise, Haertle (2012a) emphasizes the need to establish a process of continuous improvement in management education institutions in order to develop a new generation of business leaders capable of managing the complex challenges experienced by business and society in the $21^{\text {st }}$ century. It is also evident that fostering a sustainable culture centered on economic, environmental and social development significantly and strongly correlates with all other principles. The implication is that concentrating on this principle alone has the potential to develop and augment all other principles for management education. Likewise, fostering constant dialogue has the potential to enhance the alignment between PRME and research as well as create a learning environment. The intercorrelations amongst the principles for responsible management education emphasize the need for management and business schools to pledge to developing a new caliber of leaders that are capable of understanding the interrelation between the global challenges and acting effectively with new techniques, strategies, skills and efficacy to enable the required change (Copenhagen Business School, 2009, p. 1).

The results also indicate that all the principles for management education significantly correlate with sustainable development and in particular it is beneficial to focus on fostering constant dialogue to enhance economic, environmental and social development, aligning PRME and research on economic, environmental and social development and creating a learning environment conducive to economic, environmental and social development. In this regard, Young and Nagpal (2013) emphasize the importance of integrating climate and sustainability issues into the very core of business strategy and stresses that this integration begins in the curricula of business and management schools. The results reflect that only age influences academics' perceptions of the PRME and sustainable development. In particular, academics between the ages of 36-40 years are least convinced that the schools are fostering a sustainable culture, creating a learning 
environment, aligning PRME and research, fostering constant dialogue and encouraging sustainable development. Perhaps, like Nolet (2009, p. 437), academics in this age category are most aware that one cannot prolong the thinking and education practices of the past when addressing challenges of the $21^{\text {st }}$ century and believe most strongly that a new education system is needed.

The results also reflect that whilst all six principles for responsible management education are imperative for attaining sustainable development, realising sustainability in the academic environment demands constant dialogue, creating a learning environment and aligning PRME and research. In order to foster constant dialogue the Winchester Business School collaborates with non-for-profit organizations in improving their practices through consultancies. In response to creating a learning environment conducive to sustainable development, the University of Winchester has encouraged international cooperation in learning without increasing our carbon footprint and has invested in the use of interactive web technology and a range of unique learning spaces such as Stock Market Trading Simulation to enrich the student experiences and learning capabilities. In relation to aligning PRME and research the University of Winchester academic staff engages in research, knowledge exchange and inter-sector collaboration activities in the area of responsible management and sustainability (University of Winchester, 2011).

\section{Recommendations and Conclusion}

The results of the study provide guidance on how to continue to achieve those principles for responsible management education that are being achieved and how to overcome obstacles identified. In attempts to enhance the realisation of the PRME and to pursue other strategies to further its cause, the following are recommended:

- Continue to foster change/design in curricula centered on economic, environmental and social development. This can be done by scheduling time in the year planner to review all modules in the interest of incorporating PRME. Commitment can be assured by reformulating all module templates to ensure documentation and implementation. A planned and deliberate effort is needed Schoolwide. All reviews/audits should evaluate and cautiously assess the realisation of the principles for responsible management education within the modules.

- Continue to foster a sustainable culture centered on economic, environmental and social development by ensuring that the degree and modules respond to current business and societal demands. Efforts should be made to identify specific business and societal issues and to incorporate these into the curricula in terms of how they may be effectively managed.

- Creating a learning environment conducive to economic, environmental and social development. Real-life case studies, having an e-learning component, focusing more on anti-corruption in the business environment and going green should be core elements when delivering module content.

- Continue to foster PRME partnerships to enhance economic, environmental and social development with corporations that are environmentally responsible. Invite guest lecturers from organisations to enlighten students on the challenges that they face as a result of corruption, environmental degradation and/or violation of human rights and poverty.

- Ensure that the modules allow engagement on issues of recognising the right to collective bargaining and freedom of association in the work environment. This can be done by arranging seminars and open forums.

- As a part of assessments, request students to access information on anti-corruption outside of the traditional learning environment.

- The schools need to embrace going green in its daily operations. Leaders in this campaign in each school may be recognised per semester.

- Foster constant dialogue to enhance economic, environmental and social development. This can be done through dialogues, debates, discussions and presentations involving industry leaders regarding climate change, environmental degradation and its prevention.

- Aligning PRME and research on economic, environmental and social development. Encourage students and academics to engage in research centered on understanding and fighting corruption and/or brainstorming strategies for poverty reduction or that advances knowledge on climate change. Incentives relating to funding should be greater and attractive for research undertaken in 
these areas. Conference funding, research grants and other incentives may be utilised to encourage such research. PRME and sustainable development should occupy a special and prioritised session in Conferences arranged by the College.

- Ensure that lectures incorporate the values of Global Social Responsibility relating to economic, environmental and social development, emphasize that climate change is a business reality and represents an unprecedented challenge for human society and that curricula have changed to introduce climate change and other PRME issues.

In conclusion it is evident that the Graduate School of Business and the School of Management, Information Technology and Governance are adopting some aspects of the PRME. However, the focus of the education system needs to change and respond to modern societal and environmental complexities. Whilst issues on ethics and going green are easier to practice, greater energies have to be spent on developing pedagogical practice with regards to PRME to ensure sustainable development.

Recommendations for future research: This study was only undertaken in two schools within the University of KwaZulu-Natal. The study needs to be extended to all other schools at the university as educational practices in the university as a whole need to change to best meet the economic, social and environmental demands of the $21^{\text {st }}$ century if one is provide education for sustainable development.

\section{References}

Armstrong, C. M. (2011). Implementing Education for Sustainable Development: The Potential use of TimeHonored Pedagogical Practice from the Progressive Era of Education. Journal of Sustainability Education, 2, 1-25.

Bosselmann, K. (2001). University and sustainability: Compatible agendas? Educational Philosophy and Theory, 33(2), 167-186.

Copenhagen Business School. (2009). the Copenhagen Conference Declaration: A Call to Action for Management Education. Presented at the PRME/CBS International Conference on "Responsible Management Education: Sustainable Leadership in the Era of Climate Change". Retrieved 05/28/2014 fromhttp://www.unprme.org/resource-docs/CopenhagenDeclarationFINAL.pdf

Cotton, D., Bailey, I., Warren, M. \& Bissell, S. (2009). Revolutions and second-best solutions: Education for sustainable development in higher education. Studies in Higher Education, 34(7), 719-733.

De le Harpe, B. \& Thomas, I. (2009). Curriculum change in universities: Conditions that facilitate education for sustainable development. Journal of Education for Sustainable Development, 3(1), 75-78.

Egan, J. (2004). Skills for sustainable development, London: Office of the Deputy Prime Minister.

Erickson, L. E., Griswold, W., Hohn, K. L. \& Saulters, O. S. (2010). Enriching and Evaluating Sustainability Education. Journal of Sustainability Education, 1, 1-20.

Everett, J. (2008). Sustainability in higher education: Implication for disciplines. Theory and Research in Education, 6(2), 237-251.

Gebreselassie, A. T. (2010). The idea of Sustainable Development to reconcile the environment and the Intellectual Property Protection of Plants. Journal of Sustainable Development in Africa, 12(5), 125138.

Global Responsibility Leadership Initiative (GRLI). (2012). World Business School Council for Sustainable Business (WBSCSB) and Principles for Responsible Management Education (PRME): The 50/20 Agenda. Management Education for the World. GRLI, WBCSB and PRME.

Haertle, J. (2012a). Inspirational guide for the Implementation of PRME: Placing sustainability at the heart of Management education, 1-315, GSE Research, UK.

Haertle, J. (2012b). Principles for responsible management education PRME. Journal of Management Education, 36, 310-311. Retrieved 04/27/2014 fromhttp://unprme.org/about-prme/index.php.

Kevany, K. D. (2007). Building the requisite capacity for stewardship and sustainable development. International Journal of Sustainability in Higher Education, 8(2), 107-122.

Khurana, R. (2010). From Higher Aims to Hired Hands. The Social Transformation of American Business Schools and the Unfulfilled Promise of Management as a Profession, Princeton Univ. Press, N.J: Princeton. 
Khurana, R. \& Nohria, N. (2008). It's time to make management a true profession. Harvard Business Review, 86, 70-77.

Kunz, J. (2006). Social Sustainability and Community Involvement in Urban Planning, Tampere, Finland: University of Tampere. Retrieved 04/11/2014 from http://www.onlinelibrary.wiley.com.

Matten, D. \& Moon, J. (2005). Corporate social responsibility education in Europe. Journal of Business Ethics, 54(4), 323-337.

Moon, J. \& Orlitzky, M. (2011). Corporate social responsibility and sustainability education: A trans-Atlantic comparison. Journal of Management \& Organization, 17, 583-604.

Munasinghe, M. (2002). Analyzing the nexus of sustainable development and climate change: An overview, 153, Munasinghe Institute for Development (MIND), Sri Lanka. Retrieved 04/20/2014 from http://www.oecd.org/env/cc/2510070.pdf.

Nolet, V. (2009). Preparing sustainability-literate teachers. Teachers College Record, 111(2), 409-442.

Orlitzky, M. \& Moon, J. (2010). Corporate social responsibility education in Europe: Trends and comparisons, In: Swanson, D.L., Fisher, D.G. (Eds.), Toward Assessing Business Ethics Education, 143-176, Charlotte, N.C: Information Age Pub.

PRME Steering Committee. (2014). Principles for Responsible Management. Retrieved 03/27/2014 from http://unprme.org/about-prme/index.php

Rasche, A. \& Kell, G. (Eds.) (2010). The United Nations Global Compact. Achievements, Trends and Challenges, Cambridge, New York: Cambridge University Press.

Redclift, M. (2005). Sustainable development (1987-2005): an oxymoron comes of age. Sustainable Development, 13(4), 212-227.

Rode, H. \& Michelsen, G. (2008). Levels of indicator development for education for sustainable development. Environmental Education Research, 14(1), 19-33.

Sterling, S. (2001). Sustainable Education: Re-visioning Learning and Change, Schumacher Briefings No. 6. Green Books Ltd.

Sterling, A. \& Scott, W. (2008). Higher education and ESD in England: A critical commentary on recent initiatives. Environmental Education Research, 14(4), 386-398.

UNESCO. (2005). Contributing to a more sustainable future: Quality education, life skills and education for sustainable development, Paris, France: United Nations Educational, Scientific, Cultural Organization. Retrieved 01/13/2014 from http://unesdoc.unesco.org/images/0014/ 001410/141019e.pdf.

Waddock, S., Rasche, A., Wehane, P. H. \& Unruh, G. (2011). The principles for responsible management education: Implications for implementation and assessment, In: Swanson, D.L., Fisher, D.G. (Eds.), Toward Assessing Business Ethics Education, 13-28, Charlotte, N.C.: Information Age Pub.

Wals, A. E. J. (2009). A mid-DESD review: Key findings and ways forward. Journal of Education for Sustainable Development, 3(2), 195-204.

University of Winchester. (2011). Principles for Responsible Management Education: 2009-2011 Progress Report. $\quad$ Retrieved 27/10/2016 from http://www.winchester.ac.uk/academicdepartments/WBS/Principles\%20for\%20Responsible\%20 Management\%20Education/Documents/PRME\%20final.pdf

World Commission on Environment and Development (WCED). (1987). Our Common Future, Oxford University Press, Oxford.

Young, S. \& Nagpal, S. (2013). Meeting the growing demand for sustainability-focused management education: A case study of a PRME academic institution. Higher Education Research \& Development, 32(3), 493-506. 